\title{
Partial dietary fish meal replacement with cotton seed meal and supplementation with exogenous protease alters growth, feed performance, haematological indices and associated gene expression markers (GH, IGF-I) for Nile tilapia, Oreochromis niloticus
}

by Hassaan, M.S., El-Sayed, A.I.M., Soltan, M.A., Iraqi, M.M., Goda, A.M., Davies, S.J., El-Haroun, E.R. and Ramadan, H.A.

Copyright, publisher and additional information: This is the author accepted manuscript. The final published version (version of record) is available online via Elsevier.

This version is made available under the CC-BY-ND-NC licence:

https://creativecommons.org/licenses/by-nc-nd/4.0/legalcode

Please refer to any applicable terms of use of the publisher

DOI: https://doi.org/10.1016/j.aquaculture.2019.01.009

$\mathbf{H}$

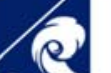

Harper Adams University

Hassaan, M.S., El-Sayed, A.I.M., Soltan, M.A., Iraqi, M.M., Goda, A.M., Davies, S.J., El-Haroun, E.R. and Ramadan, H.A. 2019. Partial dietary fish meal replacement with cotton seed meal and supplementation with exogenous protease alters growth, feed performance, haematological indices and associated gene expression markers (GH, IGF-I) for Nile tilapia, Oreochromis niloticus.

Aquaculture, 503, pp.282- 292. 
1 Partial dietary fish meal replacement with cotton seed meal and supplementation with exogenous

2 protease alters growth, feed performance, haematological indices and associated gene expression

3 markers (GH, IGF-I) for Nile tilapia, Oreochromis niloticus

4

5

6

7 H.A. Ramadan ${ }^{2}$, S.J. Davies ${ }^{3}$,

8

10

11

12

13 England, United Kingdom

$14{ }^{4}$ Animal Production Department, Faculty of Agriculture, Cairo University, Cairo, Egypt

15 *Corresponding author. Tel.: +20 1229490090; fax: +20 227943226.

16 E-mail address: ms.hassaan@niof.sci.eg (M.S. Hassaan). 
A 12-week feeding trial was conducted to evaluate the effect of different ratios of fish meal (FM): cotton seed meal (CSM) without or with inclusion of exogenous protease in diets on growth performance, hematology, digestibility and selected gene expression markers (GH and I (IGF-I) of juvenile Nile tilapia. The experimental diets were categorized into three groups; the first group $\mathrm{CSM}_{1}$ which contained fish meal protein: cotton seed meal protein (FM: CSM=2:1), the second group $\mathrm{CSM}_{2}$ which contained FM: $\mathrm{CSM}=1: 1$ and the third one $\mathrm{CSM}_{3}$ contained FM: CSM $=1: 2$ on protein content based. All groups were supplemented with exogenous protease at 0 and $2500 \mathrm{U} \mathrm{kg}^{-1}$ diet, respectively. All diets were fed to fish (initial body weight $11.62 \pm 0.03 \mathrm{~g} \mathrm{fish}^{-1}$ ) in triplicate aquaria twice daily. The higher weight gain (WG), protein efficiency ratio (PER) and best feed conversion ratio (FCR) were recorded by fish fed $\mathrm{CSM}_{1}$ and $\mathrm{CSM}_{2}$ and supplemented with 2500 U protease/ kg diet. The highest apparent digestibility coefficient of crude protein, crude lipid and digestible energy, and apparent availability coefficient of essential amino acids were obtained by fish receiving $\mathrm{CSM}_{1}$ and $\mathrm{CSM}_{2}$ supplemented with protease $\left(2500 \mathrm{U}\right.$ protease $\mathrm{kg}^{-1}$ diet). The highest mean values of $\mathrm{Hb}$, Htc and RBCs were recorded in fish fed $\mathrm{CSM}_{1}$ and $\mathrm{CSM}_{2}$ supplemented with protease enzyme (2500 $\mathrm{U}$ protease $\mathrm{kg}^{-1}$ diet). Serum of alanine and aspartate aminotransferase activities were improved due to dietary protease (2500 $\mathrm{U}$ protease $\mathrm{kg}^{-1}$ diet) supplementation, also, fish received the diets supplemented with protease $2500 \mathrm{U} \mathrm{kg}^{-1}$ diet generally had higher total protein, albumin, calcium and phosphorus than those fed diets without supplement. The highest growth hormone $(\mathrm{GH})$ gene expression in brain and liver of tilapia were obtained in the group fed $\mathrm{CSM}_{3}$ and un-supplemented with protease enzyme followed by $\mathrm{CSM}_{2}$ (un-supplemented). On the other hand, tilapia fed $\mathrm{CSM}_{1}$ and $\mathrm{CSM}_{2}$ supplemented with protease enzyme showed the highest values of gene expression of insulin like growth factor I (IGF-I) in 
50 brain and liver of tilapia compared to other groups. Results above showed that supplementation

51 of protease can improve growth, nutrient assimilation, and hematology and alter gene expression

52 of GH and IGF-I of Nile tilapia.

53 Keywords: Nile tilapia (Oreochromis niloticus), Cotton seed meal, Growth, hematology,

54 Digestibility, Gene expression, GH, insulin like growth factor I (IGF-I)

\section{Introduction}

In view of the rapid rise in aquatic animal production (fish and shrimp) there is a global

57 search for cheaper and nutritionally balanced ingredients for the manufacture of commercial

58 diets to meet this growing demand for the aquaculture industry (FAO, 2016). Traditionally fish

59 meal has been included in feeds for many species but the quest for sustainable nutrient dense

60 ingredients is high on the agenda, avoiding the ecological limits of forage fish destined for fed

61 aquaculture species (Froehlich, 2018). Plant proteins might thus be considered as the most viable

62 alternative in this respect for economic fish production in most of the developing countries (Kumar et

63 al., 2011a; Kader et al., 2012; Hassaan et al., 2018). In this manner, it has become an inevitable

64 trend of replacing fish meal with less expensive and locally available plant protein sources

65 (Hassaan et al., 2017; Hassaan et al., 2018). Cotton seed meal (CSM) has been investigated as a

66 potential alternative ingredient to both fish meal and soybean meal due to its cheaper cost, being

67 readily available in some countries, particularly in the USA, China, India and Egypt, although

68 the protein content can be variable (23-53\%) depending on how this product is processed

69 (Mbahinzireki et al., 2001; Yue and Zhou 2008). Also, CSM inclusion has been studied in

70 numerous fish species, Sarotherodon mossambicus (Jackson et al., 1982), Oreochromis niloticus

71 (Yue and Zhou 2008), Ictalurus punctatus (Robinson and Tiersch 1995), and Oncorhynchus

72 mykiss (Lee et al., 2006). These studies showed positive results at low inclusion levels, but more 
73

74

75

76

77

78

79

80

81

82

83

84

85

86

87

88

89

90

91

92

93

94

95

usually growth reduction at high inclusion levels. Among the factors which limit incorporation of

CSM into aquafeeds are amino-acid imbalance, digestibility and presence of anti-nutritional factors (ANFs) such as gossypol which impair utilization of nutrients resulting in reduced growth, nutrient utilization and feed efficiency (Francis et al., 2001; Li and Robinson 2006). To expand the use of plant-based protein for fish, it is essential to develop adequate processing technologies for plant feed ingredients in order to sufficiently remove or degrade these ANFs. There are a variety of techniques available to exclude ANFs from plant feedstuffs including soaking, dehulling, solid state fermentation and germination (Elmaki et al., 1999; Alonso et al., 2000; Idris et al., 2006; Hassan et al., 2018;). However, the use of natural bioactive agents and exogenous enzymes is gaining much attention as reported by Hlophe-Ginindza et al. 2016. The addition of such exogenous enzymes in fish diets containing high inclusion of plant protein can specifically degrade certain ANF's thus greatly enhancing the nutritional value of plant-based protein ingredients in practice (Dalsgaard et al., 2012). Furthermore, exogenous enzymes can allow flexibility in formulated feed through incorporation of lower quality and less expensive plant ingredients (Adeoye et al., 2016 a, Adeoye et al., 2016 b). In addition, exogenous enzymes may alter substrate availability for specific populations of gut microbes, which enhances digestion of nutrients and synthesis of nutrient substances that the fish need for gut integrity and growth (Jiang et al., 2014). Except for phytase, there are a few studies on the use of exogenous enzymes in fish feeds. Lin et al. (2007) reported that supplementation with a commercial enzyme complex (neutral protease, $\beta$-glucanase and xylanase) significantly improved the growth performance and feed utilization of juvenile hybrid tilapia Oreochromis niloticus $\times$ O. aureus. Drew et al. (2005) observed an increase in the apparent nutrient digestibility and an improvement in the feed efficiency when supplementing a commercial protease to a rainbow trout (Oncorhynchus mykiss) diet containing a mixture of rapeseed 
96 and pea meals. The use of a multi-enzyme complex such as Natuzyme $50^{\circledR}$ may be beneficial in

97 improving the digestibility of Kikuyu leaf meal -based diets (Hlophe and Moyo 2014). More recently, a

98 specific enzyme, exogenous protease, was suggested to be added to the feed to raise efficiency, aimed

99 to improve the dietary protein utilization of Gibel carp (Liu et al., 2018). Consequently, there is a need for further studies to establish the benefits of dietary enzyme supplementation for in vivo 101 processing of plant ingredients such as CSM into value added products for fish. Such nutritional 102 investigations can be aided by a better understanding of the underlying physiological and 103 metabolic responses of fish to dietary modulation using more advanced techniques such as nutri104 genomics.

105 Recently, new progresses in nutrition study have allowed for the integration of nutrition and 106 genomics analysis through the nutrigenomics approach, which has added to the understanding of 107 the impact of component of diet on gene expression (qRT-PCR) (Mutch et al., 2005). Further 108 advances have been made with respect to the proteome and metabolomic profile in fish to 109 substantiate the effects of nutrition on protein biosynthesis and metabolic changes. Furthermore, 110 their main mode of action is to stimulate growth, and, though IGFs share this ability with other 111 growth factors such as epidermal growth factor, platelet-derived growth factor, and nerve growth 112 factor IGFs differ from these substances in that they are quite unique in exhibiting endocrine 113 actions in higher vertebrates including the teleost. For example, nutrigenomics studies in cultured 114 fish have addressed the partial replacement of fish meal with plant protein in the diet. These 115 studies have concluded that the growth rates of fish are mediated by the growth hormone 116 (GH)/insulin-like growth factor (IGF) axis (Company et al., 2001; Pérez-Sánchez et al., 2002) as 117 well as the dietary protein sources may be affected the expression of GH-and IGF-1- encoding 118 genes (Kumar et al., 2011b). It has been suggested that both energy and protein as well as amino 
119 acid availability are required for maintenance of IGF-I. Serum IGF-I may also serve as a marker

120 for evaluation of nutritional status in humans as shown by several animal models (Ketelslegers et

121 al., 1994). However, changes in the expression of growth-related genes due to replacement of

122 fish meal with cotton seed meal with exogenous protease in tilapia have not been studied before.

123 Sustainable and balanced dietary formulations are essential and dependence on optimizing the

124 use of raw materials such as plant ingredients is critical to successful future production.

125 Therefore, the aim of the present study was to investigate the effects of a protease exogenous

126 enzyme supplement on the response of $O$. niloticus fed CSM as a partial protein concentrate

127 substitute for fish meal in a series of experimental diets under controlled laboratory conditions.

128 The main objectives were to record growth and feed utilization efficiency including digestibility,

129 and specific hematological parameters. Gene expression for growth hormone and insulin like 130 growth factor I (IGF-I) in liver and brain of tilapia was targeted to confirm any longer terms 131 metabolic responses to dietary influences on growth and development.

132 2. Materials and methods

133 2.1. Diets and experimental design

134 Six isonitrogenous (29.50\% crude protein) and isocaloric (18.76 $\left.\mathrm{MJ} \mathrm{kg}^{-1} \mathrm{gross}^{\mathrm{energy}}\right)$ 135 experimental diets were formulated and the proximate chemical composition of the experimental 136 diets is presented in Table (1). The first group CSM1 which contained fish meal protein: cotton seed 137 meal protein $(\mathrm{FM}: \mathrm{CSM}=2: 1)$, the second group $\mathrm{CSM}_{2}$ which contained FM: CSM $=1: 1$ and the 138 third one $\mathrm{CSM}_{3}$ contained FM: CSM = 1:2 on protein content based. All groups were supplemented 139 with exogenous enzyme (protease) at 0 and $0.5 \mathrm{~g} \mathrm{~kg}^{-1}$ diet. The protease (5000 $\mathrm{Ug}^{-1} \mathrm{product}_{\text {, supplied }}$ 140 by Huvepharma, Antwerp, Belgium) was added to the basal diet to provide two concentrations of 0 $141\left(0.00 \mathrm{~g} \mathrm{~kg}^{1}\right)$ and $2500\left(50 \mathrm{mg} \mathrm{kg}^{-1}\right) \mathrm{U}_{\text {protease }} \mathrm{kg}^{-1}$ diet. Activity of protease was assayed according 
142 to the method from the Committee on Food Chemicals Codex (1996). One protease unit was the

143 amount of enzyme that releases $1.0 \mu \mathrm{g}$ of phenolic compound, expressed as tyrosine equivalents,

144 from a casein substrate per minute at $\mathrm{pH} 7.5$ and $40{ }^{\circ} \mathrm{C}$. The analyzed activity of protease was

$1454395 \mathrm{U} \mathrm{g}^{-1}$. All dry ingredients i.e. fishmeal, cotton seed meal, soybean meal, yellow corn and wheat

146 bran were blended for 5 mins and thoroughly mixed with soybean oil. Also, each of the diets

147 contained $5 \mathrm{~g} \mathrm{~kg}^{-1}$ chromic oxide $\left(\mathrm{Cr}_{2} \mathrm{O}_{3}\right)$ as a marker for nutrient digestibility measurements. The

148 ingredients were mixed well and made into dry pellets using a laboratory pellet mill (California Pellet

149 Mill, San Francisco, CA, USA) and air dried at $37{ }^{\circ} \mathrm{C}$ overnight. The pellets (2-mm die) were

150 subsequently stored at $-20^{\circ} \mathrm{C}$ until subsequent use.

151

152

153 154 with hydrochloric acid, followed by separation of the pure compound, as assayed by HPLC

155 according to the method of Luo et al. (2006).

\subsection{Determination of gossypol in cotton seed meal}

Free gossypol concentration in the experimental diets was determined by high-performance liquid chromatography (HPLC). Extraction of free gossypol by acetone was performed after hydrolysis acording to the method of Luo et al. (2006).

The activity of exogenous enzymes was estimated according to the method described Shi et respectively. Each group after mixed was incubated with buffer solution $\left(\mathrm{Na}_{2} \mathrm{~B}_{4} \mathrm{O}_{7} \cdot\left(\mathrm{H}_{2} \mathrm{O}\right)_{10-}\right.$ $\left.\mathrm{H}_{2} \mathrm{BO}_{3}, \mathrm{pH} 8.5\right)$ containing penicillin and streptomycin $\left(200 \mathrm{U} \mathrm{ml}^{-1}\right)$ for $2 \mathrm{~h}$ at a temperature of solution) standard curve using a spectrophotometer at OD $570 \mathrm{~nm}$. The amount of free amino acid hydrolyzed by the exogenous protease in the diets of $\mathrm{CSM}_{1}, \mathrm{CSM}_{2}$ and $\mathrm{CSM}_{3}$ (with or 
without protease supplementation) and occurred naturally in fish meal were compared. The difference of free amino acid content between diet (with or without protease supplementation) was shown. The exogenous protease activity in original products was $87.9 \%$ activity.

\subsection{Fish and experimental conditions}

Nile tilapia, O. niloticus fingerlings (approximately 11-11.5 g) from a private farm (Kafer Elsheekh Governorate, Egypt), were transferred to the Fish Nutrition Laboratory, Faculty of Agriculture, Benha University, and kept in two 450 L- capacity tanks for prior acclimatization. Fish were fed daily on the basal diet (30\% crude protein and $18.90 \mathrm{MJ} \mathrm{kg}^{-1}$ gross energy). After an acclimatization period of 15 days, 216 fish were randomly distributed into six groups with three replicates, each replicate contained 12 fish (avg. wt. $11.60 \pm 0.72 \mathrm{~g}$ ) in an aquarium (100 L capacity). Fresh water was supplied to each aquarium housed within an artificially illuminated room with a photoperiod of $12 \mathrm{~h}$ light: $12 \mathrm{~h}$ dark regime. All aquaria were supplied with compressed air for oxygen requirements throughout the experimental period. Six groups of experimental fish were fed close to apparent satiation twice per day at 09:00 and 14:00 h. Total fish weight in each aquarium estimated every 2 weeks to check their growth. About one-third of water volume in each aquarium was replaced daily by fresh water after removing the accumulated feces by siphoning. Water quality was measured throughout the experiment for all essential parameters. During the 84 days of feeding trial, the water-quality parameters averaged as follows: water temperature ranged from 27.85 to $29.33^{\circ} \mathrm{C}$ : dissolved oxy-gen, ranged between 5.56 and $6.65 \mathrm{mg} \mathrm{L}^{-1}$ : water total ammonia ranged from 0.16 to $0.2 \mathrm{mg} \mathrm{L}^{-1}$ : and $\mathrm{pH}$, ranged between 8.04 and 8.30 . It noticed that, the reported water quality parameters in this study were within the normal ranges for fish growth (Boyd, 1990).

\subsection{Growth performance and feed utilization indices}


During the feeding period, the fish per aquarium were counted, weighed and measured for body weight individually every two weeks. The following measurements and equations were applied to fish to indicate the growth performance and feed utilization criteria.

Weight gain (WG) = Final body weight (FBW g) - Initial body weight (IBW g); Specific growth rate $(\mathrm{SGR})=(\ln \mathrm{FBW}-\ln \mathrm{IBW}) / \mathrm{t} \times 100$, Where: $\ln$ is natural logarithmic of FBW and

$191 \mathrm{IBW} ; \mathrm{t}=$ time in days; Feed conversion ratio $(\mathrm{FCR})=$ Feed intake $(\mathrm{g}) /$ weight gain $(\mathrm{g})$; Protein 192 efficiency ratio $(\mathrm{PER})=$ weight gain $(\mathrm{g}) /$ protein intake $(\mathrm{g})$.

\subsection{Digestibility measurements}

The apparent digestibility coefficients (ADCs) and amino acids apparent availability of different experimental diets were determined using chromic oxide $\left(\mathrm{Cr}_{2} \mathrm{O}_{3}\right)$ as an external marker 196 at a level of $0.5 \%$ within the diet. After a two-month feeding period for the experimental diets, 197 feces were collected from each aquarium once daily prior to feeding for a one-month period. The 198 collection was done manually by siphoning the faecal matter and straining through a fine-meshed 199 net (Baruah et al., 2007). Faecal matter collected was pooled in each aquarium and subsequently dried in a hot air oven at $60{ }^{\circ} \mathrm{C}$. Dried feces were digested in a mixture of perchloric acid and 201 nitric acid mixture $(2: 1)$ at $250{ }^{\circ} \mathrm{C}$, according to the method described by Zhou et al. (2004). 202 After appropriate dilution chromic oxide was determined according to the procedure described 203 by Furukawa and Tsukahara (1966). The following equation determined the ADCs and amino 204 acids apparent availability of the experimental diets: $\mathrm{ADCs}=\left[100-\left(\mathrm{Cr}_{2} \mathrm{O}_{3} \%\right.\right.$ in $\operatorname{diet} / \mathrm{Cr}_{2} \mathrm{O}_{3} \%$ in 205 faces $) \times($ nutrient $\%$ in faces $/$ nutrient $\%$ in diet $)] \times 100$. 


\subsection{Chemical composition and amino acid}

Proximate chemical analyses were made for the experimental diets and samples of fish (five fish in each replicate) at end of the experiment according to standard methods AOAC, (1990) for dry matter, crude protein, ether extract, crude fiber and ash. Dry matter was determined by oven drying at $105^{\circ} \mathrm{C}$ until a constant weight was achieved. Crude protein $(\mathrm{N} \times 6.25)$ was determined using the Kjeldahl method after acid digestion using an Auto Kjeldahl System (UDK 126 D, Italy). Crude lipid was determined by the ether-extraction method using a Soxtec System HT (Soxtec System HT6, Tecator) with diethyl ether $\left(40-60{ }^{\circ} \mathrm{C}\right)$. The ash content was estimated after incineration the samples in a muffle furnace at $550{ }^{\circ} \mathrm{C}$ for $24 \mathrm{~h}$. Fiber content of the experimental diets was determined using the method described by Van Soest et al. (1991). Nitrogen-free extract (NFE) was computed by taking the sum of values for crude protein, crude lipid, crude fiber and ash and by subtracting this sum from 100. The samples of diets and fecal for amino acid analysis were ground following by digestion using $10 \mathrm{~mL} \mathrm{6N} \mathrm{HCl}$ solution at 110 ${ }^{\circ} \mathrm{C}$ for $24 \mathrm{~h}$. Amino acids were separated using high performance liquid chromatography (HPLC; Shimadzu Corp., Tokyo, Japan) following the method showed by Kader et al. (2010). The hydrolyzed amino acids composition of the experimental diets was showed in Table 2.

\subsection{Hematological and blood chemistry parameters}

At the end of the experiment, blood samples (five fish in each replicate) were collected from the caudal vein of all treatments from anaesthetized fish with overdose of tricaine methanesulfonate (MS-222; $\left.1 \mathrm{~g} \mathrm{~L}^{-1}\right)$. Blood samples were divided into two portions. The first portion was collected with anticoagulant $10 \%$ ethylenediaminetetraacetate (EDTA) to determine the hematocrit (Htc), hemoglobin $(\mathrm{Hb})$, erythrocyte counts (RBCs) and total count of white blood cells (WBCs) according to standard methods as described elsewhere by Rawling et al. (2009). The second 
231 portion of the blood sample was allowed to clot overnight at $4^{\circ} \mathrm{C}$ and then was centrifuged at 3000

$232 \mathrm{rpm}$ for $10 \mathrm{~min}$. The non-hemolysed serum was collected and stored at $-20^{\circ} \mathrm{C}$ until use. Levels of 233 serum aspartate aminotransferase (AST), alanine aminotransferase (ALT) were determined 234 according to the method described by Reitman and Frankel (1957) and serum creatinine was 235 measured by the calorimetric method and enzymatic determination methods as described by Henry 236 et al. (1974). Total serum protein and albumin were determined according to Henry (1964) and 237 Wotton and Freeman (1974), respectively. However, the total serum globulin was calculated by 238 subtracting the total serum albumin from the total serum protein according to Coles (1974). Serum 239 phosphorus and calcium were measured spectrophotometrically using commercial kits produced by 240 Pasteur labs (Egyptian American Co. for Laboratory Services, Egypt).

241 2.9. Gene expression analysis

242 2.9.1. RNA extraction

243 Total RNA was isolated from liver and pituitary samples (three fish in each replicate) using a 244 Promega RNA Isolation Kit (Cat No. Z3100, USA) according to the manufacturer's instructions. 245 The quantity of the RNA was assessed using a Nano-Drop spectrophotometer (NANODROP 246 1000, Thermo Scientific, USA). The integrity (quality) was checked by denaturing gel 247 electrophoresis (1\% agarose gel) and the purity by measuring the OD260/OD280 absorption ratio $248(>1.95)$.

249 2.9.2. First strand cDNA synthesis

250 cDNA was generated from $1 \mu \mathrm{g}$ of total RNA using High Capacity cDNA (Thermo Fisher 251 Scientific, Cat. No .436, 8814) reverse transcriptase kit for reverse transcriptase polymerase 
252 chain reaction (RT-PCR) following the manufacturer's protocol. The product of the first strand

253 cDNA synthesis was stored at $-80^{\circ} \mathrm{C}$ until the quantitative RT-PCR (qRT-PCR) runs.

254 2.9.3. Real-time quantitative RT-PCR

255 The primers employed for the quantification of the desired genes were purchased from 256 Invitrogen, Germany. The primer sequences and calculated efficiency are enlisted in Table 3.

257 Triplicate qPCR reactions were performed on an AriaMx Real-Time PCR System (Agilent 258 technologies). Reactions containing $5 \mu \mathrm{l}$ of $5 \times$ diluted cDNA, 10 pmol each of forward and 259 reverse primers, $0.4 \mu \mathrm{l}$ ROX dye solution (1:500 dilution) and $10 \mu \mathrm{l}$ SYBR Green PCR 260 MasterMix (Maxima SYBR Green qPCR, Thermo Fisher Scientific, Cat. No \# k0251) were 261 performed in a four-step experimental run protocol: a denaturation program $\left(10 \mathrm{~min}\right.$ at $\left.95^{\circ} \mathrm{C}\right)$; an 262 amplification and quantification program repeated 40 times $\left(30 \mathrm{~s}\right.$ at $95{ }^{\circ} \mathrm{C}, 50 \mathrm{~s}$ at $55^{\circ} \mathrm{C}$ and $40 \mathrm{~s}$ 263 at $\left.72^{\circ} \mathrm{C}\right)$; a melting curve program $\left(55-95^{\circ} \mathrm{C}\right.$ with a heating rate of $0.10^{\circ} \mathrm{C} / \mathrm{s}$ and a continuous 264 fluorescence measurement) and finally a cooling step. Melt curve analyses of the target genes 265 and reference genes resulted in single products with specific melting temperatures. In addition, 266 "no-template" controls (i.e. with water sample) for each set of genes were also run to ensure no 267 contamination of reagents, no primer-dimer formation. Moreover, 18S rRNA gene was used as 268 an internal standard. The relative mRNA expression levels were calculated by a standard curve 269 method. The expression levels of genes were normalized to the levels of 18S rRNA gene in the 270 same sample. Standard curves were generated by serial dilution of a random mixture of control 271 samples.

\section{2.10.Statistical analysis}


273 All data were analyzed by using the software SAS, version 6.03 (Statistical Analysis System

274 1996). One-way analysis of variance (One-way ANOVA) was used to determine whether

275 significant variation existed between the treatments. When overall differences were found,

276 differences between means were tested by Tukey's HSD test. Two-way ANOVA was used for

277 analyzing the individual effects of FM: CSM ratios and protease level and the interaction between

278 them. All differences were considered significant at $\mathrm{P}<0.05$ and the results are presented as

279 means with pooled standard error of the mean (Pooled S.E.M).

280 3. Results

281 3.1. Relative rate of exogenous protease activity

282 Relative activity of exogenous protease of CSM1, CSM2 and CSM3 diets were $70.45 \%$,

$28368.03 \%$ and $67.99 \%$, respectively, when compared with the activity of protease in original

284 product $(87.9 \%)$ (Table 4$)$.

285 3.2. Growth performance

286 Body weight gains ( $\mathrm{g}$ ) of tilapia are shown in Figure 1 as affected by different ratios of FM: CSM; 2:1,

$287 \quad 2: 2$ and 1:2 and exogenous protease levels 0 or $2500 \mathrm{U} \mathrm{kg}^{-1}$ and their interaction. Mean bi-weekly body

288 mass gain revealed that fourth week onwards; there was differential growth among the treatments, and the

289 lower body mass gain was observed in fish fed $\mathrm{CSM}_{3}$ without protease. The effects of FM: CSM

290 ratios, protease and their interaction on the growth performance and feed utilization for treated

291 groups are presented in Table 5. All indices of growth and feed utilization were significantly

292 affected by FM: CSM ratios, protease and their interaction, except $\mathrm{FI}(\mathrm{P}=0.288, \mathrm{P}=0.097$ and $\mathrm{P}$

$293=0.790$, respectively). Although, there was a significant interaction between FM:CSM ratio and

294 protease, fish fed the diets supplemented with protease $2500 \mathrm{U} \mathrm{kg}^{-1}$ diet generally had greater 
295 WG, FCR and PER than those fed the basal diets; growth performance and feed utilization 296 generally decreased with decreasing FM:CSM ratios. The highest WG, FCR and PER were 297 recorded by fish fed $\mathrm{CSM}_{1}$ and $\mathrm{CSM}_{2}$ and supplemented with $2500 \mathrm{U}$ protease $\mathrm{kg}^{-1}$ diet.

298

299

300

301

302

303

304

305

306

307

308

309

310

311

312

313

314

315

316

\subsection{Apparent digestibility coefficient}

Results of the apparent digestibility coefficient (ADCs) of dry matter, protein lipid and digestible energy, are shown in Table 6 . The ADCs of dry matter, crude protein, crude lipid and digestible energy (DE) were significantly affected by FM: CSM ratios, protease and their interaction. Generally, ADC of dry matter $(\mathrm{P}=0.001)$, crude protein $(\mathrm{P}=0.017)$, crude lipid $(\mathrm{P}=0.021)$ and digestible energy $(\mathrm{P}=0.013)$ were improved in fish fed diet supplemented with $2500 \mathrm{U}$ protease $\mathrm{kg}^{-1}$ diet compared with un-supplemented diet. The highest ADC of dry matter crude protein, crude lipid and digestible energy was obtained by fish fed $\mathrm{CSM}_{1}$ and $\mathrm{CSM}_{2}$ supplemented with protease (2500 $\mathrm{U}$ protease $\mathrm{kg}^{-1}$ diet).

\subsection{Amino acids apparent availability}

The effects of protease enzyme, different ratios of FM: CSM and their interaction on the essential amino acid apparent availability of Nile tilapia are shown in Table 7. Apparent availability of essential amino acids was significantly $(\mathrm{P}<0.05)$ affected by dietary different ratio of FM:CSM, supplementation with exogenous protease and their interaction. Although there was a significant interaction between FM:CSM ratio and protease, fish fed the diets supplemented with protease $2500 \mathrm{U} \mathrm{kg}^{-1}$ diet generally had greater of apparent availability of essential amino acids than those fed the basal diets. The highest apparent availability of essential amino acids was noted in fish fed $\mathrm{CSM}_{1}$ and $\mathrm{CSM}_{2}$ supplemented with protease $2500 \mathrm{U}$ protease $\mathrm{kg}^{-1}$ diet. 
317

318

319

320

321

322

323

324

325

326

327

328

329

330

331

332

333

334

335

336

337

338

\subsection{Chemical composition}

Data of the proximate chemical composition of whole fish are presented in Table 8 . No significant differences due to FM: CSM ratios, protease and their interaction were observed for all indices of chemical composition, except crude protein $(\mathrm{P}=0.035)$. The lowest content of crude protein was recorded by fish fed $\mathrm{CSM}_{2}$ without supplemented exogenous protease. Both $\mathrm{CSM}_{1}$ groups without and with supplemental protease had significantly higher crude protein than other groups.

\subsection{Hematology indices}

The effects of protease enzyme, different ratios of FM: CSM and their interaction on the hematology parameters of Nile tilapia are shown in Table 9. With exception of WBC $(\mathrm{P}=$

$0.781 ; \mathrm{P}=0.051 ; \mathrm{P}=0.072), \mathrm{FM}: \mathrm{CSM}$ ratios, exogenous protease and their interaction had significant effect on $\mathrm{Hb}, \mathrm{Htc}$ and RBCs of Nile tilapia. $\mathrm{Hb}(\mathrm{P}=0.026)$, Htc $(\mathrm{P}=0.041)$ and RBCs $(\mathrm{P}=0.049)$ values were significantly higher in fish fed diet supplemented with exogenous protease $2500 \mathrm{U} \mathrm{kg}^{-1}$ diet in comparison with the other diet without supplemented.

\subsection{Blood biochemistry}

The effects of FM: CSM ratios, exogenous protease and their interaction on serum of ALT, AST activities, total protein, albumin, globulin, calcium and phosphorus for Nile tilapia are presented in Table 10. With exception, globulin $(\mathrm{P}=0.121 ; \mathrm{P}=0.321 ; \mathrm{P}=0.221)$, FM: CSM ratios, exogenous protease and their interaction had significant effect on serum of ALT, AST, total protein, albumin, calcium and phosphorus of Nile tilapia. Although there was a significant interaction between FM:CSM ratio and protease, fish received diets supplemented with protease $2500 \mathrm{U} \mathrm{kg}^{-1}$ diet generally had lower ALT, AST and higher total protein, albumin, calcium and 
339 phosphorus than those fed the basal diets (without supplemented). The best ALT, AST, total 340 protein, albumin, calcium and phosphorus were recorded by fish fed $\mathrm{CSM}_{1}$ and $\mathrm{CSM}_{2}$ 341 supplemented with $2500 \mathrm{U}$ protease $\mathrm{kg}^{-1}$ diet.

342

\subsection{Gene expression}

Table 11, Figure 2 and 3 illustrated gene expression of growth hormone $(\mathrm{GH})$ in brain and liver of tilapia as influenced by different ratios of FM: CSM and exogenous protease levels and their interaction. Gene expression of growth hormone $(\mathrm{GH})$ in brain and liver were significantly affected by different ratios of FM: CSM and exogenous protease levels and their interaction (Table 10). Relative growth hormone (GH) gene expression was significantly down-regulated in pituitary $(\mathrm{P}=0.012)$ and liver $(\mathrm{P}=0.021)$ of fish fed different ratios of FM: CSM supplemental with exogenous protease after 84 days (Figure 2). Furthermore, the highest GH expression in brain and liver of tilapia were observed in fish fed $\mathrm{CSM}_{3}$ without supplemental exogenous protease. Gene expression of insulin like growth factor I (IGF-I) in brain and liver of tilapia are shown in Figure 3 which was affected by different ratios of FM: CSM and exogenous protease enzyme level and their interaction. Fish fed different ratios of FM: CSM supplemented with protease enzyme showed the highest expression of IGF-I gene as compared to other treatments.

\section{Discussion}

In the present study, Nile tilapia fed different ratios of FM:CSM; CSM $1, \mathrm{CSM}_{2}$ and $\mathrm{CSM}_{3}$ and supplemented with $2500 \mathrm{U}$ exogenous protease $\mathrm{kg}^{-1}$ diet yielded the highest growth performance and feed utilization compared to fish fed the similar diets with no added exogenous protease. Inclusion levels of dietary cotton seed meal (CSM) that can be used as a plant protein source for tilapia diets depend mainly on the level of free gossypol and available lysine content (El-Saidy 
361 and Gaber, 2004). The reduction of growth performance in this study for Nile tilapia fed varying 362 inclusion ratio of $\mathrm{CSM}$, i.e. $\mathrm{CSM}_{1}, \mathrm{CSM}_{2}$ and $\mathrm{CSM}_{3}$ without supplemented with protease levels

363 (Table 1) were consistent with Nile tilapia fed dietary levels of CSM at $240 \mathrm{~g} \mathrm{~kg}^{-1}$ diet (Robinson 364 et al. 1984) and rainbow trout fed up $200 \mathrm{~g} \mathrm{~kg} \mathrm{diet}^{-1}$ with CSM (Cheng and Hardy 2002) and 365 these results may be attributed to the presence of gossypol and low biological availability of 366 lysine (Francis et al., 2001; Ofojekwu and Ejike (1984). On the contrary, there were no 367 significant effects found in hybrid tilapia and rainbow trout with dietary levels of CSM (337.6 368 and $588 \mathrm{~g} \mathrm{~kg}^{-1}$ diet, respectively (Yue and Zhou, 2008; Lee et al., 2006). In the present study, 369 supplementation of protease enzyme (2500 $\mathrm{U}$ protease $\mathrm{kg}^{-1}$ diet) mitigated some of these 370 negative effects. Many studies have reported that exogenous enzyme supplementation can 371 eliminate the effect of ANFs (Hlophe-Ginindza et al., 2016; Adeoye et al., 2016) and enhance 372 the utilization of protein and amino acids, resulting in improved growth performance of fish 373 (Farhangi and Carter 2007; Lin et al. 2007; Baruah et al. 2007; Soltan 2009; Hussain et al. 2015). 374 In addition, exogenous proteases may increase endogenous peptidase production, raise protease 375 activity and subsequently improve the digestibility of dietary protein leading to fast assimilation 376 and increased growth as well as being capable of increasing accessibility of nutrients by breaking 377 down and disrupting layers of complex proteins in plant cell walls (Caine et al., 1998). In 378 contrast, Dalsgaard et al. (2012) found no significant differences in growth performance of 379 rainbow trout fed three different plant-based feedstuffs (soybean, rapeseed, sunflower) a 380 supplemented with mixture of exogenous enzymes ( $\beta$-glucanase, xylanase and protease).

381 In this study, the highest apparent digestibility of crude protein, crude lipid and gross energy 382 in diets were attributed to the protease supplementation with the enzyme assisting in minimizing 383 the action of Anti-Nutritional Factors such as gossypol and releasing more protein for 
384 assimilation. Likewise, Liu et al. (2018) showed that supplementing $400 \mathrm{mg} \mathrm{kg}^{-1} \mathrm{protease}$, to a 385 low protein diet, could save $20 \mathrm{~g} \mathrm{~kg}^{-1}$ dietary protein, improve Apparent Digestibility 386 Coefficients (ADC) of crude protein and crude lipid and having no harmful effects on juvenile 387 Gibel carp (Carassius auratus gibelio) health. Similarly, Drew et al. (2005) showed that 388 supplementation with $250 \mathrm{mg} / \mathrm{kg}$ protease to a diet containing coextruded canola and pea meal 389 (1:1) improved ADC of protein, lipid, energy and dry matter of rainbow trout with similar 390 supplementation enzyme levels used in the present study with tilapia. In contrast, enzyme 391 supplementation to feed had no noticeable impact on aquatic animal production as viewed by 392 Divakaran and Velasco (1999) and Miller et al. (2008). This may be due to exogenous enzymes 393 being thermally degraded during feed processing such as with extrusion causing deactivation of 394 their activities. These differences in results might be explained by diet composition, including 395 the nutrition level and plant ingredient inclusion level and conditions of storage.

396 The present data clarified that, no significant $(\mathrm{P}>0.05)$ effect were detected among different 397 fish groups for whole body composition, except protein content FM:CSM, exogenous protease 398 supplementation and their interaction. This finding agrees with the study of Lin et al. (2007) who 399 revealed that tilapia fed exogenous commercial enzyme complex (neutral protease, b-glucanase 400 and xylanase) have displayed no significant differences in whole body moisture, protein, lipid 401 and ash.

402 Hematological parameters are useful for monitoring fish general health and physiological 403 responses to stress, reducing $\mathrm{Htc}$ and $\mathrm{HB}$ of fish in one of the most common indicators of 404 harmful effect of free gossypol (Mbahinzireki et al., 2001; Garcia-Abiado et al., 2004). In the 405 current study, Hb, Htc, RBCs and WBCs were higher in tilapia fed different ratios of CSM $\mathrm{C}_{1}$ and $406 \mathrm{CSM}_{2}$ and supplemented with protease enzyme (2500 $\mathrm{U}_{\text {protease }} \mathrm{kg}^{-1}$ diet) than counterpart diets 
407 not supplemented with exogenous protease, which indicated that exogenous protease could 408 inhibit the deleterious effect of free gossypol in diets (Table 6). To the best of our knowledge, 409 there are no studies describing the effects of dietary protease supplementation on hematological 410 parameters of fish when fed a diet containing gossypol. Although, Goda et al. (2012) found that 411 red blood cell count, hematocrit and hemoglobin were significantly $(\mathrm{P}<0.05)$ elevated in all 412 treatments fed supplemented diets with mixtures of exogenous digestive enzymes (pepsin, papain 413 and $\alpha$-amylase). On the other hand, supplementation with a mixed enzyme cocktail had no 414 effects on hematological parameters of Nile tilapia as reported recently by Adeoye et al. (2016a). 415 Moreover, the measurement of AST and ALT is indicative of general systemic nutritional 416 status as well as the integrity of the vascular system and liver function (Kumar et al., 2011a). 417 Increased activities of serum AST and ALT in fish may reveal possible leakage of enzymes 418 across damaged plasma membranes and/or increased synthesis of enzymes by the liver (Yang 419 and Chen, 2003). In a study with Gilthead sea bream (Sparus aurata) Gómez-Requeni et al. 420 (2004) reported that dietary treatment did not alter the hepatic activity of amino acid catabolizing 421 enzymes AST, ALT, glutamate dehydrogenase when fish meal was replaced up to 100\% with a 422 mixture of plant protein concentrates. Direct hepatic measurements of these enzymes were not 423 performed in this study with tilapia, although plasma activities were undertaken to indirectly 424 assess liver status.

425 The present study with tilapia showed that the plasma activity of AST and ALT in fish fed 426 high inclusion level of CSM without protease supplementation was higher than those fed high 427 inclusion level of CSM and supplemented with exogenous protease. These results indicated that 428 dietary protease could improve the metabolic processes of liver and kidney of fish when 429 challenged with elevated plant ingredients in the diet. This is in contrast to the findings of Cai et 
430 al. (2011) observed that dietary inclusion of CSM up to a concentration of $400 \mathrm{~g} \mathrm{~kg}^{-1}$ diet did not 431 alter plasma levels of ALT and AST of crucian carp (Carassius auratus gibelio $q \times$ Cyprinus 432 carpio ${ }^{\Uparrow}$ ). However, Liu et al. (2018) found that diets for rainbow trout containing CSM 433 supplemented with $600 \mathrm{mg} \mathrm{kg}^{-1}$ protease achieved the minimum serum level of ALT and AST 434 activities. These serum biochemical indices are usually employed to assess the nutritional and 435 health status of fish (Hassaan et al., 2017). The increase rate of anabolic processes in fish may be 436 due to increases in serum protein level to meet increased metabolic demands in fast growing fish, 437 and the cyclic nature of the total serum protein is an indicator of the changes taking place in the 438 serum globulin fraction (Helmy et al., 1974). Increases in proteinogram levels are thought to be 439 associated with a stronger innate response in fish (Jha et al., 2007). Globulin level is very often 440 used as an indicator of immune responses and a source of antibody production (Blazer and 441 Wolke, 1984). In the present study, protease supplementation appeared to increase the levels of 442 total protein, globulin and albumin in the serum of Nile tilapia fed diets with high inclusion level 443 of CSM and supplemented with exogenous protease (Table 7).

444 Growth hormone (GH) initiates many of its growth-promoting actions by binding to GH 445 receptors (GHRs) and stimulating the synthesis and secretion of insulin-like growth factor-I (IGF446 I) from the liver (Reindl et al., 2011). Cao et al. (2009) reported that IGF-1 is an important 447 hormone involved in the growth and development of carp. In the present study, relative growth 448 hormone $(\mathrm{GH})$ gene expression was significantly $(\mathrm{P}<0.05)$ down-regulated in pituitary and liver 449 of fish fed different ratios of FM: CSM and supplemented with exogenous protease. 450 Furthermore, there was a negative correlation between GH gene and growth performance.

451 The highest growth performance value was recorded by tilapia fed $\mathrm{CSM}_{1}$ and $\mathrm{CSM}_{2}$ and 452 supplemented with $2500 \mathrm{U}$ protease/ $\mathrm{kg}$ diet, but the expression of $\mathrm{GH}$ gene exhibited the 
453 opposite trend. This finding was also confirmed by Pierce et al. (2005) who reported that 454 transcription of the GH gene was significantly $(\mathrm{P}<0.05)$ higher during extended periods of fasting 455 or feed restrictions for Chinook salmon (Oncorhynchus tshawytscha). In our study, tilapia received 456 their nutritional requirements according to apparent satiation, but fish fed $\mathrm{CSM}_{2}$ and $\mathrm{CSM}_{3}$ and un457 supplemented with protease showed lowered feed utilization than other diets which were 458 supplemented with exogenous protease. These diets, in turn led to elevated expression of GH in 459 both brain and liver of fish possibly indicating a lower plane of nutrition and growth rate.

460 In this context, GH has important functions during inferior nutritional conditions and may serve 461 to spare protein use for energy and preferentially mobilize energy from stored lipid (Björnsson et 462 al., 2002). Protein malnutrition not only decreases IGF-I production rate, but also enhances its 463 serum clearance and degradation. Our results with tilapia are consistent the findings of Gómez464 Requeni et al. 2004 with Gilthead sea bream indicating that the activity of the GH-liver axis was 465 affected by dietary treatment. In comparison to fish fed a 100\% FM diet, these latter investigators 466 reported increased circulating GH levels paralleled the decrease in circulating IGF-I levels. 467 However, a limitation in our study with tilapia was the lack of information regarding the plasma 468 level of these hormones for direct comparison.

469 In the present study, tilapia fed different FM: CSM ratios (2:1 and 1:1) and supplemented 470 with a protease enzyme showed the highest expression of IGF-I gene as compared to the other 471 treatment groups. From this data, there appeared a negative correlation between GH gene 472 expression and that of the IGF-I gene. Our results are therefore similar to those obtained by Duan, 473 (1998) who also reported there are negative correlations between IGF-I and GH in fish and the 474 high secretion level of GH was detected in fish during starvation to promote lipolysis. Our results 475 are also consistent with those acquired by Gómez-Requeni et al. (2004), Dyer et al. (2004). 
476 Gómez-Requeni et al. (2004) and with Aksnes et al. (2006) who also concluded that, rainbow

477 trout and gilthead seabream fed diets containing $75 \%$ of plant protein mixtures replacing fish

478 meal protein gave the highest GH gene expression in liver probably caused by lower growth

479 rates on such diets due mainly to essential amino acid imbalance, and reduced availability of 480 protein for effective biosynthesis and anabolic pathways. There is evidence for selective organ 481 resistance to the growth-promoting effects of IGF-I in protein-restricted rats (Thissen et al., 482 1994). All this revealed a state of GH-liver desensitization, a characteristic feature of catabolic 483 states. In the fasting rat model, liver growth hormone $(\mathrm{GH})$ binding is decreased, providing one 484 explanation for decreased IGF-I (Ketelslegers et al., 1995). This may be more acute in 485 carnivorous fish compared to species like tilapia with a better ability to assimilate such low 486 protein diets. Gabillard et al. (2002) reported that although temperature seems to promote growth 487 through IGF-I secretion by the liver following GH stimulation, an impairment of nutritional 488 status would prevent the IGF-I stimulation and this may validate our findings with tilapia albeit 489 reared at a constant $28^{\circ} \mathrm{C}$. Gómez-Requeni et al. (2004) were the first to describe simultaneous 490 and nutritionally regulated changes in mRNA transcripts of GHR and IGF-I in fish species in 491 their experiments with seabream; although in our study we did not attempt to explore the GH 492 Receptor transcript for tilapia under the experimental conditions. It should be cautioned however, 493 that gene expression data does not always imply a functionality response in terms of the generation 494 of 'active' proteins synthesized during the post-translation of mRNA at the ribosomal level and 495 where proteins are modified such as in glycosylation, phosphorylation, and methylation by 496 enzymatic processes within the cell. It will be important to measure actual circulating hormonal 497 and associated metabolites directly in fish for further clarification as stated previously. 
However, to the authors' knowledge, this is the first-time gene expression was measured in tilapia fed diets with different ratios of FM:CSM supplemented with exogenous protease. This requires further studies to establish the effect of exogenous digestive enzymes on tilapia gene

501 expression that relate to growth and feed utilization as well as many other metabolic factors and to 502 provide practical as well as scientific value to design more efficient feed formulations for tilapia 503 and other fish species.

504 In conclusion, this investigation has provided good evidence for the benefits associated with 505 the addition of an exogenous enzyme (protease) in association with high plant ingredient 506 inclusion, namely CSM as one example. This is becoming an important technology to realizing 507 the promise of greatly enhancing the nutritional quality and value of plant by-products in 508 practical fish diets. Indeed, exogenous enzymes are being used successfully as functional feed 509 additives and supplements to enhance digestion and growth in fish in the commercial sector. 510 These will need to take into account processing techniques such as extrusion technologies where 511 the higher temperatures encountered can modify and reduce enzyme activities and effects on any 512 beneficial bioactive components that may be thermo-labile. It is evident that further research and 513 development is needed in these areas to fully appraise these products as viable dietary 514 supplements for fish and especially for tilapia.

\section{$515 \quad$ References}

516 Adeoye, A.A., Jaramillo-Torres, A., Fox, S.W., Merrifield, D.L. Davies, S.J., $2016 a$. 517 Supplementation of formulated diets for tilapia (Oreochromis niloticus) with selected 518 exogenous enzymes: Overall performance and effects on intestinal histology and 519 microbiota. Animal Feed Science and Technology 215, 133-143. 
Adeoye, A.A., Yomla, R., Jaramillo-Torres, A., Rodiles, A., Merrifield, D. L., Davies, S.J., 2016b. Combined effects of exogenous enzymes and probiotic on Nile tilapia (Oreochromis niloticus) growth, intestinal morphology and microbiome. Aquaculture 463, 61-70.

Aksnes, A., Hope, B., Jönsson, E., Björnsson, B. T., Albrektsen, S., 2006. Size-fractionated fish hydrolysate as feed ingredient for rainbow trout (Oncorhynchus mykiss) fed high plant protein diets. I: Growth, growth regulation and feed utilization. Aquaculture 261(1), 305-317.

Alonso, R., Aguirre, A., Marzo, F., 2000. Effects of extrusion and traditional processing methods on anti-nutrients and in vitro digestibility of protein and starch in faba and kidney beans. Food Chemistry 68, 159-165.

AOAC. (1990). Official methods of analysis. Virginia: Arlington. 1117p.

Baruah, K., Sahu, N.P., Pal, A.K., Jain, K.K., Debnath, D., Mukherjee, S.C., 2007. Dietary microbial phytase and citric acid synergistically enhances nutrient digestibility and growth performance of Labeo rohita (Hamilton) juveniles at sub-optimal protein level. Aquaculture Research 38(2), 109-120.

Björnsson, B.T., Johansson, V., Benedet, S., Einarsdottir, I.E., Hildahl, J., Agustsson, T., Jönsson, E., 2002. Growth hormone endocrinology of salmonids: regulatory mechanisms and mode of action. Fish Physiology and Biochemistry 27(3-4), 227-242.

Blazer, V.S., Wolke, R.E. 1984. The effects of $\alpha$-tocopherol on the immune response and nonspecific resistance factors of rainbow trout (Salmo gairdneri Richardson). Aquaculture 37(1), $1-9$.

Boyd, C.E., 1990. Water quality in ponds for aquaculture. Alabama Agricultural Experiment Station, Auburn University. Alabama P462. 
542 Björnsson, B.T., Johansson, V., Benedet, S., Einarsdottir, I.E., Hildahl, J., Agustsson, T., 543 Jönsson, E., 2002. Growth hormone endocrinology of salmonids: regulatory mechanisms and 544 mode of action. Fish Physiology and Biochemistry 27(3-4), 227-242.

545 Cai, C., Li, E., Ye, Y., Krogdahl, A., Jiang, G., Wang, Y., Chen, L., 2011. Effect of dietary 546 graded levels of cotton seed meal and gossypol on growth performance, body composition 547 and health aspects of allogynogenetic silver crucian carp, Carassius auratus gibelio $q \times$ 548 Cyprinus carpio $\widehat{\jmath}$. Aquaculture nutrition 17(4), 353-360.

549 Caine, W., Verstegen, M., Sauer, W., Tamminga, S., Schulze, H., 1998. Effect of protease 550 treatment of soybean meal on content of total soluble matter and crude protein and level of $551 \quad$ soybean trypsin inhibitors. Animal Feed Science and Technology 71, 177-183.

552 Cao, Y., Chen, X., Wang, S., Chen, X. C., Wang, Y.X., Chang, J.P., Du, J.Z., 2009. Growth 553 hormone and insulin-like growth factor of naked carp (Gymnocypris przewalskii) in Lake 554 Qinghai: expression in different water environments. General and Comparative $555 \quad$ Endocrinology 161, 400-406.

556 Cheng, Z. J., Hardy, R.W., 2002. Apparent digestibility coefficients and nutritional value of 557 cotton seed meal for rainbow trout (Oncorhynchus mykiss). Aquaculture 212(1), 361-372.

558 Coles, M. G., 1974. Physiological activity and detection: The effects of attentional requirements and 559 the prediction of performance. Biological Psychology 2(2), 113-125.

560 Committee on Food Chemicals Codex, 1996. Food Chemicals Codex, Fourth ed. National Academy 561 Press, Washington, DC.

562 Company, R., Astola, A., Pendón, C., Valdivia, M. M., Pérez-Sánchez, J., 2001. Somatotropic 563 regulation of fish growth and adiposity: Growth hormone (GH) and somatolactin (SL) 564 relationship. Comparative Biochemistry and Physiology 130C, 435-445. 
Dalsgaard, J., Verlhac, V., Hjermitslev, N., Ekmann, K. S., Fischer, M., Klausen, M., Pedersen, P. B., 2012. Effects of exogenous enzymes on apparent nutrient digestibility in rainbow trout (Oncorhynchus mykiss) fed diets with high inclusion of plant-based protein. Animal Feed Science and Technology 171(2-4), 181-191.

Divakaran, S., Velasco, M., 1999. Effect of proteolytic enzyme addition to a practical feed on growth of the Pacific white shrimp, Litopenaeus vannamei (Boone). Aquaculture Research 30, 335-339.

Drew, M. D., Racz, V. J., Gauthier, R., Thiessen, D. L., 2005. Effect of adding protease to coextruded flax: Pea or canola: Pea products on nutrient digestibility and growth performance of rainbow trout, Oncorhynchus mykiss. Animal Feed Science and Technology 119, 117-128.

Duan, C., 1998. Nutritional and developmental regulation of insulin-like growth factors in fish. Journal of Nutrition 128, 306S-314S.

Elmaki, H.B., Babiker, E.E., El-Tinay, A.H., 1999. Changes in chemical composition, grain malting, starch and tannin contents and protein digestibility during germination of sorghum cultivars. Food Chemistry 64, 331-336.

El-Saidy, D.M.S.D., Gaber, M.M.A., 2004. Use of cotton seed meal supplemented with iron for detoxification of gossypol as a replacement of fish meal in Nile tilapia, Oreochromis niloticus (L.) diets. Aquaculture Research 35, 859-869.

FAO, I., 2016. WFP (2015), The State of Food Insecurity in the World 2015. Meeting the 2015 international hunger targets: taking stock of uneven progress. Food and Agriculture Organization Publications, Rome.

Farhangi M., Carter, C.G., 2007. Effect of enzyme supplementation to dehulled lupin-based diets on growth, feed efficiency, nutrient digestibility and carcass composition of rainbow trout, Oncorhynchus mykiss (Walbaum). Aquaculture Research 38, 1274-1282. 
Francis, G., Maakar, H.P.S., Becker, K., 2001. Anti-nutritional factors present in plant-derived alternate fish feed ingredients and their effects in fish. Aquaculture 199, 197-227.

Froehlich, H. E., Jacobsen, N. S., Essington, T. E., Clavelle, T., Halpern, B. S., 2018. Avoiding the ecological limits of forage fish for fed aquaculture. Nature Sustainability 1(6), 298.

Furukawa, A., Tsukahara, H., 1966. On the acid digestion method for the determination of chromic oxide as an index substance in the study of digestibility of fish feed. Bulletin of the Japanese Society of Scientific Fisheries 32, 502-504.

Gabillard J.C., Weil, C, Rescan, P.Y., Navarro, I., Gutiérrez, J., Le Bail P. Y., 2002. Effects of environmental temperature on IGF1, IGF2, and IGF type I receptor expression in rainbow trout (Oncorhynchus mykiss). General Comparative Endocrinology 133 (2), 233-42.

Gómez-Requeni, P., Mingarro, M., Calduch-Giner, J. A., Médale, F., Martin, S. A. M., Houlihan, D. F., Pérez-Sánchez, J., 2004. Protein growth performance, amino acid utilization and somatotropic axis responsiveness to fish meal replacement by plant protein sources in gilthead sea bream (Sparus aurata). Aquaculture 232(1-4), 493-510.

Goda, A.M.A., Mabrouk, H.A.-H.H., Wafa, M.A.E.-H., El-Afifi, T.M., 2012. Effect of using baker's yeast and exogenous digestive enzymes as growth promoters on growth, feed utilization and hematological indices of Nile tilapia, Oreochromis niloticus fingerlings. Journal of Agricultural Science and Technology B 2, 15-28.

Hassaan, M. S., Goda, M. A-S., Kumar, V., 2017. Evaluation of nutritive value of fermented deoiled Physic nut, Jatropha curcas seed meal for Nile tilapia, Oreochromis niloticus fingerlings. Aquaculture nutrition 23(3), 571-584.

Hassaan, M. S., Soltan, M. A., Mohammady, E. Y., Elashry, A. M., El-Haroun, E. R., Davies, S. J., 2018. Growth and physiological responses of Nile tilapia, Oreochromis niloticus fed 
dietary fermented sunflower meal inoculated with Saccharomyces cerevisiae and Bacillus subtilis. Aquaculture 495, 592-601.

613

614

615

616

617

618

619

620

621

622

623

624

625

626

627

628

629

630

631

632

Helmy, A.M., Badawi, H. K., El-Bishry, A., 1974. Seasonal variations in the protein composition of blood serum of Anguilla vulgaris and Mugill cephalus. Egyptian Journal of Aquatic Research 4, 369-375.

Henry, R. J., 1964. Clinical Chemistry: Principles and Technics. [With a Bibliography]. Hoeber Medical Division, Harper \& Row.

Henry, R. J., Cannon, D. C., Winkleman, J. W., 1974. Automated determination of serum and urine creatinine. Clinical chemistry, principles and techniques. New York, NY: Harper and Row.

Hlophe S.N., Moyo, N.A.G., 2014. Evaluation of kikuyu grass and moringa leaves as protein sources in Oreochromis mossambicus diet. African Journal of Aquatic Sciences 39, 305-312.

Hlophe-Ginindza, S. N., Moyo, N. A., Ngambi, J. W., Ncube, I., 2016. The effect of exogenous enzyme supplementation on growth performance and digestive enzyme activities in Oreochromis mossambicus fed kikuyu-based diets. Aquaculture Research 47(12), 3777-3787

Hussain, S. M., Afzal, M., Javid, A., Hussain, A. I., Ali, Q., Mustafa, I., Chatha, S. A. S., Shah, S.Z. H., Hussain, M. Ullah, M.I., 2015. Efficacy of phytase supplementation on growth performance and mineral digestibility of Labeo rohita fingerlings fed on cotton seed meal based diet. Pakistan Journal of Zoology 47(3), 699- 709.

Idris, W.H., Abdel Rahaman, S.M., ElMaki, H.B., Babiker, E.E., El Tinay, A.H., 2006. Effect of malt pretreatment on phytate and tannin level of two sorghum (Sorghum bicolor) cultivars. International Journal of Food Science and Technology 41, 1229-1233. 
633 Jackson, A.J., Capper, B.S., Matty, A.J., 1982. Evaluation of some plant proteins in complete 634 diets for the tilapia Sarotherodon mossambicus. Aquaculture 27, 97-109.

635 Jha, A. K., Pal, A., Sahu, N., Kumar, S., Mukherjee, S. 2007. Haemato-immunological responses 636 to dietary yeast RNA, $\omega-3$ fatty acid and $\beta$-carotene in Catla catla juveniles. Fish and 637 Shellfish Immunology 23, 917-927.

638 Jiang, T.T., Feng, L., Liu, Y., Jiang, W.D., Jiang, J., Li, S.H., Zhou, X.Q., 2014. Effects of 639 exogenous xylanase supplementation in plant protein-enriched diets on growth performance, 640 intestinal enzyme activities and microflora of juvenile Jian carp (Cyprinus carpio var. Jian). 641 Aquaculture Nutrition 20(6), 632-645.

642 Kader, A., Koshio, S., Ishikawa, M., Yokoyama, S., Bulbul, M., Nguyen, B.T., Gao, J., Laining, 643 A., 2012. Can fermented soybean meal and squid by-product blend be used as fishmeal 644 replacements for Japanese flounder (Paralichthys olivaceus) Aquaculture Research 43, 1427$645 \quad 1438$.

646 Kader, M. A., Koshio, S., Ishikawa, M., Yokoyama, S., Bulbul, M., (2010). Supplemental 647 effects of some crude ingredients in improving nutritive values of low fishmeal diets for 648 red sea bream, Pagrus major. Aquaculture, 308(3-4), 136-144.

649 Ketelslegers, J.M, Maiter, D., Maes, M., Underwood, L.E., Thissen J. P., 1995. Nutritional 650 regulation of insulin-like growth factor-I. Metabolism 44, 50-7.

651 Kumar, V., Makkar, H., Becker, K., 2011a. Nutritional, physiological and haematological 652 responses in rainbow trout (Oncorhynchus mykiss) juveniles fed detoxified Jatropha curcas 653 kernel meal. Aquaculture Nutrition 17, 451-467.

654 Kumar, V., Khalil, W. K. B., Weiler, U., Becker, K., 2011b. Influences of incorporating 655 detoxified Jatropha curcas kernel meal in common carp (Cyprinus carpio L.) diet on the 

expression of growth hormone-and insulin-like growth factor-1-encoding genes. Journal of 657 Animal Physiology and Animal Nutrition 97, 97-108.

658 Lee, K. J., Rinchard, J., Dabrowski, K., Babiak, I., Ottobre, J.S., Christensen, J. E., 2006. Long659 term effects of dietary cotton seed meal on growth and reproductive performance of rainbow 660 trout: three-year study. Animal Feed Science and Technology 126, 93-106.

661 Li, M. H. Robinson, E. H. 2006. Use of cotton seed meal in diets of aquatic animals: a review. 662 North American Journal of Aquaculture 68, 14-22.

663 Li, M. H., Peterson, B.C., Janes, C.L., Robinson, E.H., 2006. Comparison of diets containing 664 various fish meal levels on growth performance, body composition, and insulin-like growth 665 factor-I of juvenile channel catfish Ictalurus punctatus of different strains. Aquaculture 253, $666 \quad 628-635$.

667 Lin S., Mai K., Tan B., 2007. Effects of exogenous enzyme supplementation in diets on growth 668 $669 \quad$ Research 38, 1645-1653.

670 Liu, W., Wu, J., Li, Z., Duan, Z., Wen, H., 2018. Effects of dietary coated protease on growth 671 performance, feed utilization, nutrient apparent digestibility, intestinal and hepatopancreas 672 structure in juvenile Gibel carp (Carassius auratus gibelio). Aquaculture Nutrition 24(1), 47$673 \quad 55$

674 Luo L., Xue, M., Wu X., Cai X., Cao, H., Liang, Y., 2006. Partial or total replacement of fish 675 meal by solvent-extracted cotton seed meal in diets for juvenile rainbow trout (Oncorhynchus 676 mykiss). Aquaculture Nutrition 12, 418-424. 
677 Mbahinzireki, G. B., Dabrowski, K., Lee, K. J., El-Saidy, D., Wisner, E. R., 2001. Growth, feed 678 utilization and body composition of tilapia (Oreochromis sp.) fed cotton seed meal-based 679 diets in a recirculating system. Aquaculture Nutrition 7(3), 189-200.

680 Miller, D.R., Granzin, B.C., Elliott, R., Norton, B.W., 2008. Effects of an exogenous enzyme, 681 Roxazyme G2 Liquid, on milk production in pasture fed dairy cows. Animal Feed Science $682 \quad$ and Technology 145, 194-208.

683 Mutch, D. M., Wahli, W., Williamson, G. 2005. Nutrigenomics and nutrigenetics: The emerging 684 faces of nutrition. The FASEB Journal 19, 1602-1616.

685 Anh, N.T.L., Kunhareang, S., Duangjinda, M., 2015. Association of chicken growth hormones 686 and insulin-like growth factor gene polymorphisms with growth performance and carcass 687 traits in Thai broilers. Asian-Australasian journal of animal sciences 28(12), 1686.

688 Ofojekwu, P.C., Ejike, C., 1984. Growth response and feed utilization in the tropical cichlid 689 Oreochromis niloticus (Linn.) fed on cotton seed-based artificial diets. Aquaculture, 42(1), $690 \quad 27-36$.

691 Pérez-Sánchez, J., Calduch-Giner, J. A., Mingarro, M., de Celis, S. V. R., Gómez-Requeni, P., 692 Saera-Vila, A., Valdivia, M. M., 2002. Overview of fish growth hormone family. New 693 insights in genomic organization and heterogeneity of growth hormone receptors. Fish 694 Physiology and Biochemistry 27(3-4), 243-258.

695 Pierce, A.L., Shimizu, M., Beckman, B.R., Baker, D.M., Dickhoff, W.W., 2005. Time course of 696 the GH/IGF-I axis response to fasting and increased ration in Chinook salmon (Oncorhynchus 697 tshawytscha). General and Comparative Endocrinology 140, 192-202. 
Rairakhwada, D., Pal, A. K., Bhathena, Z. P., Sahu, N. P., Jha, A., Mukherjee, S. C., 2007. Dietary microbial levan enhances cellular non-specific immunity and survival of common carp (Cyprinus carpio) juveniles. Fish \& shellfish Immunology 22(5), 477-486.

Rawling, M.D., Merrifield, D.L., Davies, S.J., 2009. Preliminary assessment of dietary supplementation of Sangrovit on red tilapia (Oreochromis niloticus) growth performance and health. Aquaculture 294, 118-122.

Reitman, S. Frankel, S., 1957. A colorimetric method for the determination of serum glutamic oxaloacteic and glutamic pyruvic transaminases. American. Journal of Clinical. Pathology 28, 56.

Robinson, E.H., Rawles, S.D., Oldenburg, P.W., Stickney, R.R., 1984. Effects of feeding glandless or glanded cotton seed products and gossypol to Tilapia aurea. Aquaculture 38(2), 145-154.

Robinson, E.H., Tiersch, T.R., 1995. Effects of long-term feeding of cotton seed meal on growth, testis development, and sperm motility of male channel catfish Ictalurus punctatus brood fish. Journal of the World Aquaculture Society 26, 426-431

Santiago, C. B., Lovell, R.T., 1988. Amino acid requirements for growth of Nile tilapia. The journal of nutrition 118 (12), 1540-1546.

Shi, Z., Li, X.Q., Chowdhury, M.K., Chen, J.N., Leng, X.J., 2016. Effects of protease supplementation in low fish meal pelleted and extruded diets on growth, nutrient retention and digestibility of gibel carp, Carassius auratus gibelio. Aquaculture 460, 37-44.

Soltan M.A., 2009. Effect of dietary fish meal replacement by poultry by- product meal with different grain source and enzyme supplementation on performance, faeces recovery, body composition and nutrient balance of Nile tilapia. Pakistan Journal of Nutrition 8, 395-407. 
721 Thissen J.P., Ketelslegers, J.M., Underwood, L.E., 1994. Nutritional regulation of the insulin722 like growth factors. Endocrine Reviews 15 (1), 80-101.

723 Thissen, J.P., Underwood, L., Ketelslegers, J.M., 1998. Nutritional Regulation of Hepatic 724 Production of IGF-1. In Nutritional Aspects of Osteoporosis (pp. 119-130). Springer, New $725 \quad$ York, NY.

726 Van Soest, P. V., Robertson, J., Lewis, B., 1991. Methods for dietary fiber, neutral detergent 727 fiber, and nonstarch polysaccharides in relation to animal nutrition. Journal of Dairy Science $728 \quad 74(10), 3583-3597$.

729 Wotton, I. D., and Freeman, H., 1974. Microanalysis in medicinal biochemical. Churchill 730 Livingstone Press, Edinburgh, London.

731 Yang, J. L., Chen, H. C., 2003. Serum metabolic enzyme activities and hepatocyte ultrastructure 732 of common carp after gallium exposure. Zoological Studies 42, 455-461.

733 Yue, Y. R., Zhou, Q.C., 2008. Effect of replacing soybean meal with cotton seed meal on 734 growth, feed utilization, and hematological indexes for juvenile hybrid tilapia, Oreochromis 735 niloticus $\times$ O. aureus. Aquaculture 284(1-4), 185-189. 
Table 1 Formulation and proximate composition of the experimental diets ( $\mathrm{g} \mathrm{kg}^{-1}$ dry matter)

\begin{tabular}{|c|c|c|c|c|c|c|}
\hline & \multicolumn{6}{|c|}{ Experimental diets } \\
\hline & \multicolumn{2}{|r|}{${ }^{9} \mathrm{CSM}_{1}$} & \multicolumn{2}{|r|}{${ }^{\dagger} \mathrm{CSM}_{2}$} & \multicolumn{2}{|c|}{${ }^{\ddagger} \mathrm{CSM}_{3}$} \\
\hline & FM:CSM;2:1 & FM:CSM;2:1+protease & FM:CSM; $1: 1$ & FM:CSM; $1: 1+$ protease & FM:CSM;1:2 & FM:CSM;1:2+protease \\
\hline Fish meal & 150 & 150 & 110 & 110 & 80 & 80 \\
\hline Soybean meal & 300 & 300 & 300 & 300 & 300 & 300 \\
\hline Cotton seed meal $\dagger$ & 120 & 120 & 160 & 160 & 230 & 230 \\
\hline Yellow corn & 220 & 220 & 220 & 220 & 220 & 220 \\
\hline Wheat bran & 150 & 150 & 150 & 150 & 110 & 110 \\
\hline soybean oil & 40 & 40 & 40 & 40 & 40 & 40 \\
\hline Vitamin \&Minerals $^{1}$ & 14.50 & 14.00 & 14.50 & 14 & 14.50 & 14 \\
\hline Vitamin $\mathrm{C}$ & 0.5 & 0.5 & 0.5 & 0.5 & 0.5 & 0.5 \\
\hline Chromic oxide & 5 & 5 & 5 & 5 & 5 & 5 \\
\hline Protease & - & 0.5 & - & 0.5 & - & 0.5 \\
\hline \multicolumn{7}{|l|}{ Proximate analysis } \\
\hline Dry matter & 900.10 & 898.10 & 897.00 & 892.90 & 898.90 & 895.60 \\
\hline Crude protein & 298.50 & 297.00 & 296.00 & 295.00 & 296.20 & 295.10 \\
\hline Ether extract & 75.00 & 72.40 & 70.00 & 67.90 & 72.40 & 73.50 \\
\hline Ash & 60.20 & 59.10 & 58.60 & 58.20 & 59.10 & 59.60 \\
\hline Fiber content & 51.00 & 49.00 & 50.00 & 51.00 & 52.90 & 52.80 \\
\hline $\mathrm{NFE}^{2}$ & 515.30 & 522.50 & 525.40 & 527.90 & 519.40 & 519.00 \\
\hline Gross energy $\left(\mathrm{MJkg}^{-1}\right)^{3}$ & 18.85 & 18.84 & 18.77 & 18.71 & 18.76 & 18.78 \\
\hline Free gossypol $\left(\mathrm{mg} \mathrm{kg}^{-1}\right)$ & 230.16 & 230.19 & 300.88 & 300.85 & 430.03 & 430.04 \\
\hline $\begin{array}{l}{ }^{1} \text { Vitamin and mineral } 1 \\
4.0 \mathrm{~g}, \text { Pantothenic acid } \\
\text { Selenium. folic acid, } 1 \\
39 \% \mathrm{Na}, 61 \% \mathrm{Cl}), 30 \\
\mathrm{mg} ; \text { copper sulfate } \\
\text { content). }{ }^{3} \mathrm{Gross} \text { energy } \\
{ }^{9} \mathrm{CSM}_{1}=(\mathrm{FM}: \mathrm{CSM}, 2\end{array}$ & $\begin{array}{l}\text { nixture } \mathrm{kg}^{-1} \text { of mi } \\
8.0 \mathrm{~g} \mathrm{Nicotinic} \mathrm{a} \\
2 \mathrm{mg} \text {; niacin, } 12 \\
77 \mathrm{mg} \text {; ferrous su } \\
\mathrm{CuSO}_{4} .5 \mathrm{H}_{2} \mathrm{O}, 25 \\
\text { calculated using } \\
1) ;{ }^{+} \mathrm{CSM}_{2}=\text { (FN }\end{array}$ & $\begin{array}{l}\text { ixture contains: } 4800 \mathrm{I} . \mathrm{U} . \\
\text { cid, } 400 \mathrm{mg} \text { Folic acid, } 20 \\
\text { mg; d-calcium pantothena } \\
\text { lfate (FeSO } 4.7 \mathrm{H}_{2} \mathrm{O}, 20 \% \mathrm{~F} \\
\% \mathrm{Cu}), 28 \mathrm{mg} \text {; potassium } \\
\text { gross calorific values of } 2 \\
\text { a:CSM, 1:1) ; }{ }^{\circ} \mathrm{CSM}_{3}=(\mathrm{F}\end{array}$ & $\begin{array}{l}2400 \mathrm{IU} \text { choleca } \\
\text { 3iotin, } 200 \text { gm Cl } \\
\text { mg; pyridoxine. } \\
\text { 5mg; manganese } \\
\text { e (KI, } 24 \% \mathrm{~K}, 76 \\
39.52 \text { and } 17.15 \\
\mathrm{SM}, 1: 2)\end{array}$ & $\begin{array}{l}\text { ferol (vit. D), } 40 \mathrm{~g} \text { Vit E, } 8 \\
\text { ine, } 4 \mathrm{~g} \text { Copper, } 0.4 \mathrm{~g} \text { Iodin } \\
\mathrm{Cl}, 6 \mathrm{mg} \text {; riboflavin, } 7.2 \mathrm{mg} \\
\text { fate }(\mathrm{MnSO}, 46 \% \mathrm{Mn}), 89 \\
\mathrm{I}),{ }^{2} \mathrm{NFE}(\mathrm{Nitrogen} \text { free ext } \\
\mathrm{g}^{-1} \text { for protein, fat and carbo }\end{array}$ & $\begin{array}{l}\text {, } 4.0 \mathrm{~g} \text { Vit } \mathrm{B}_{12} \text {, } \\
\text { Iron, } 22 \mathrm{~g} \mathrm{Man} \\
\text { in. } \mathrm{HCl}, 1.2 \mathrm{mg} \text {; } \\
\text { inc sulfate }(\mathrm{ZnS} \\
\text { lo0-(crude prote } \\
\text { e, respectively a }\end{array}$ & $\begin{array}{l}\text { Vit B2, } 6 \mathrm{~g} \text { Vit B6, } \\
\text { ee, } 22 \mathrm{~g} \text { Zinc, } 0.04 \mathrm{~g} \\
\text { um chloride }(\mathrm{NaCl} \text {, } \\
\left.\mathrm{H}_{2} \mathrm{O}, 40 \% \mathrm{Zn}\right), 150 \\
\text { ipid + ash }+ \text { fiber } \\
\text { ding to Brett (1973). }\end{array}$ \\
\hline
\end{tabular}


Table 2 Hydrolyzed amino acids composition of experimental diets (\%)

\begin{tabular}{lcccc}
\hline \multirow{2}{*}{ Essential amino acid } & \multicolumn{3}{c}{ Experimental diets } & \multirow{2}{*}{ Requirements of tilapia $^{\#}$} \\
\cline { 2 - 4 } & $\mathrm{CSM}_{1}$ & $\mathrm{CSM}_{2}$ & $\mathrm{CSM}_{3}$ & 1.18 \\
\hline Arginine & 2.12 & 2.02 & 1.96 & 0.48 \\
Histidine & 0.87 & 0.88 & 0.84 & 1.43 \\
Lysine & 2.11 & 1.95 & 1.78 & 0.75 \\
Methionine & 1.24 & 1.23 & 1.19 & 0.87 \\
Leucine & 2.42 & 2.44 & 2.35 & 0.87 \\
Isoleucine & 1.12 & 1.02 & 0.96 & 1.05 \\
Threonine & 1.59 & 1.54 & 1.52 & 1.05 \\
Phenylalanine & 1.49 & 1.53 & 1.51 & 0.78 \\
Valine & 1.53 & 1.51 & 1.45 & \\
\hline
\end{tabular}

"Requirements as percentage of dry diet for tilapia (Santiago and Lovell 1988) 
Table 3 List of real time qPCR assays used in this experiment

\begin{tabular}{llcc}
\hline \multicolumn{1}{c}{ Gene } & \multicolumn{1}{c}{ Primers } & Amplicon (bp) & GenBank no. \\
\hline 18s & F: GGTTGCAAAGCTGAAACTTAAAGG & 85 & AF497908.1 \\
rRNA & R: TTCCCGTGTTGAGTCAAATTAAGC & & \\
IGF-I & F: GTTTGTCTGTGGAGAGCGAGG & 97 & Y10830.1 \\
& R: GAAGCAGCACTCGTCCACG & & \\
GH & F: TCGACAAACACGAGACGCA & 75 & M2916
\end{tabular}
F: Forward primer
$\mathrm{R}$ : Reverse primer 


\begin{tabular}{|c|c|c|c|}
\hline & \multicolumn{3}{|c|}{ Experimental diets } \\
\hline & $\mathrm{CSM}_{1}(\mathrm{FM}: \mathrm{CSM} ; 2: 1)$ & $\mathrm{CSM}_{2}$ (FM: CSM; 1:1) & $\mathrm{CSM}_{3}$ (FM: CSM; 1:2) \\
\hline Without protease $\left(\mathrm{mg} \mathrm{mL}^{-1}\right)$ & $15.92 \pm 0.51$ & $14.86 \pm 0.56$ & $13.78 \pm 0.32$ \\
\hline With protease $\left(\mathrm{mg} \mathrm{mL}^{-1}\right)$ & $21.13 \pm 0.38$ & $18.89 \pm 0.68$ & $17.46 \pm 0.49$ \\
\hline Difference $\left(\mathrm{mg} \mathrm{mL}^{-1}\right)$ & $5.21 \pm 0.35$ & $4.12 \pm 0.18 \mathrm{~b}$ & $3.86 \pm 0.24$ \\
\hline Relative activity of protease $\dagger \%$ & $70.45 \pm 3.19$ & $68.03 \pm 2.54$ & $67.99 \pm 3.69$ \\
\hline
\end{tabular}


Table 5 Growth response and feed utilization of Nile tilapia fed experimental diets for 84 days

\begin{tabular}{|c|c|c|c|c|c|c|}
\hline \multirow{2}{*}{ FM:CSM ratios } & \multirow{2}{*}{ Protease $\mathrm{U} \mathrm{kg}^{-1}$} & \multicolumn{2}{|c|}{ Growth performance } & \multicolumn{3}{|c|}{ Feed utilization } \\
\hline & & $\mathrm{IBW}^{1}\left(\mathrm{~g} \mathrm{fish}^{-1}\right)$ & $\mathrm{WG}^{2}\left(\mathrm{~g} \mathrm{fish}^{-1}\right)$ & $\mathrm{FI}^{3}\left(\mathrm{~g} \mathrm{fish}^{-1}\right)$ & $\mathrm{FCR}^{4}$ & PER $^{5}$ \\
\hline \multicolumn{7}{|c|}{ 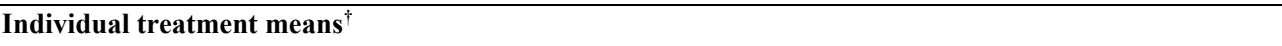 } \\
\hline $\mathrm{CSM}_{1}(2: 1)$ & 0 & 11.54 & $29.92^{\mathrm{c}}$ & 40.92 & $1.37^{\mathrm{a}}$ & $2.43^{\mathrm{b}}$ \\
\hline $\mathrm{CSM}_{1}(2: 1)$ & 2500 & 11.62 & $34.56^{\mathrm{a}}$ & 41.92 & $1.21^{\mathrm{b}}$ & $2.75^{\mathrm{a}}$ \\
\hline $\operatorname{CSM}_{2}(1: 1)$ & 0 & 11.63 & $27.58^{\mathrm{d}}$ & 38.72 & $1.41^{\mathrm{a}}$ & $2.38^{\mathrm{c}}$ \\
\hline $\mathrm{CSM}_{2}(1: 1)$ & 2500 & 11.67 & $33.23^{\mathrm{a}}$ & 41.12 & $1.25^{\mathrm{b}}$ & $2.69^{\mathrm{a}}$ \\
\hline $\mathrm{CSM}_{3}(1: 2)$ & 0 & 11.96 & $26.96^{\mathrm{d}}$ & 39.05 & $1.45^{\mathrm{a}}$ & $2.30^{\mathrm{c}}$ \\
\hline $\mathrm{CSM}_{3}(1: 2)$ & 2500 & 11.50 & $31.45^{\mathrm{b}}$ & 40.61 & $1.29^{\mathrm{b}}$ & $2.58^{\mathrm{a}}$ \\
\hline \multicolumn{2}{|l|}{ Pooled S.E.M } & 0.02 & 1.18 & 0.99 & 0.063 & 0.123 \\
\hline \multicolumn{7}{|c|}{ Two-way ANOVA (p-value) } \\
\hline \multicolumn{2}{|l|}{ FM: CSM } & 0.968 & 0.045 & 0.288 & 0.045 & 0.042 \\
\hline \multicolumn{2}{|l|}{ Protease } & 0.874 & 0.004 & 0.097 & 0.011 & 0.025 \\
\hline \multicolumn{2}{|c|}{ FM: CSM $\times$ Protease } & 0.961 & 0.041 & 0.790 & 0.032 & 0.021 \\
\hline
\end{tabular}

\footnotetext{
${ }^{\dagger}$ Treatments means represent the average values of three aquaria per treatment. Duncan multiple range test was conducted for individual means only if there was a significant interaction (ANOVA: $\mathrm{P}<0.05$ ). Pooled S.E. $M^{\star}=$ pooled standard error of the mean. Means followed by the same letter are not significantly different.

$\mathrm{IBW}^{1}=$ initial body weightWG ${ }^{2}=$ weight gain; $\mathrm{FI}^{3}=$ feed intake $\mathrm{g}^{-1}$ fish; $\mathrm{FCR}^{4}=$ feed conversion ratio; $\mathrm{PER}^{5}=$ protein efficiency ratio.
} 
Table 6 Apparent digestibility coefficient (\%) of Nile tilapia fed experimental diets for 84 days

\begin{tabular}{|c|c|c|c|c|c|}
\hline \multirow{2}{*}{ FM:CSM ratios } & \multirow{2}{*}{$\begin{array}{l}\text { Protease } \mathrm{U} \mathrm{kg}^{-} \\
1\end{array}$} & \multicolumn{4}{|c|}{ Apparent digestibility coefficient (\%) } \\
\hline & & Dry matter & Crude protein & Crude lipid & Digestible energy \\
\hline \multicolumn{6}{|c|}{ Individual treatment means ${ }^{\dagger}$} \\
\hline $\operatorname{CSM}_{1}(2: 1)$ & 0 & $92.65^{\mathrm{c}}$ & $88.40^{\mathrm{b}}$ & $90.31^{\mathrm{b}}$ & $84.62^{\mathrm{b}}$ \\
\hline $\mathrm{CSM}_{1}(2: 1)$ & 2500 & $94.25^{\mathrm{a}}$ & $90.46^{\mathrm{a}}$ & $91.75^{\mathrm{a}}$ & $87.00^{\mathrm{a}}$ \\
\hline $\mathrm{CSM}_{2}(1: 1)$ & 0 & $93.50^{\mathrm{b}}$ & $86.66^{\mathrm{c}}$ & $90.17^{\mathrm{b}}$ & $83.20^{\mathrm{b}}$ \\
\hline $\mathrm{CSM}_{2}(1: 1)$ & 2500 & $94.20^{\mathrm{a}}$ & $89.55^{\mathrm{a}}$ & $92.05^{\mathrm{a}}$ & $86.50^{\mathrm{a}}$ \\
\hline $\mathrm{CSM}_{3}(1: 2)$ & 0 & $93.45^{\mathrm{b}}$ & $85.35^{\mathrm{c}}$ & $89.57^{\mathrm{c}}$ & $83.65^{\mathrm{b}}$ \\
\hline $\mathrm{CSM}_{3}(1: 2)$ & 2500 & $93.22^{\mathrm{b}}$ & $88.40^{\mathrm{b}}$ & $90.16^{\mathrm{b}}$ & $86.18^{\mathrm{a}}$ \\
\hline Pooled S.E.M ${ }^{\pi}$ & & 0.113 & 0.493 & 0.556 & 0.749 \\
\hline \multicolumn{6}{|c|}{ Two-way ANOVA (p-value) } \\
\hline FM: CSM & & 0.022 & 0.006 & 0.412 & 0.425 \\
\hline Protease & & 0.069 & 0.002 & 0.012 & 0.021 \\
\hline FM: CSM $\times$ Pro & ase & 0.001 & 0.017 & 0.021 & 0.013 \\
\hline
\end{tabular}

${ }^{\dagger}$ Treatments means represent the average values of three aquaria per treatment. Duncan multiple range test was conducted for individual means only if there was a significant interaction (ANOVA: $\mathrm{P}<0.05$ ). Pooled S.E.M $\mathrm{M}^{\uparrow}=$ pooled standard error of the mean. Means followed by the same letter are not significantly different. 
Table 7 Apparent availability coefficients (\%) of essential amino acids in experimental diets for Nile tilapia



${ }^{\dagger}$ Treatments means represent the average values of three aquaria per treatment. Duncan multiple range test was conducted for individual means only if there was a significant interaction (ANOVA: $\mathrm{P}<0.05$ ). Pooled S.E. $\mathrm{M}^{\uparrow}=$ pooled standard error of the mean. Means followed by the same letter are not significantly different 
Table 8 Proximate composition ( $\mathrm{g} \mathrm{kg}^{-1}$ dry matter) of Nile tilapia fed diet fed experimental diets for 84 days

\begin{tabular}{lccccc}
\hline FM:CSM ratios & Protease $\mathrm{U} \mathrm{kg}^{-1}$ & Dry matter & Crude protein & Total lipid & Ash \\
\hline Individual treatment means & ${ }^{\dagger}$ & & & & \\
$\mathrm{CSM}_{1}(2: 1)$ & 0 & 272.60 & $153.10^{\mathrm{a}}$ & 51.60 & 38.50 \\
$\mathrm{CSM}_{1}(2: 1)$ & 2500 & 261.30 & $146.70^{\mathrm{a}}$ & 49.40 & 39.10 \\
$\mathrm{CSM}_{2}(1: 1)$ & 0 & 251.20 & $138.90^{\mathrm{c}}$ & 47.20 & 35.20 \\
$\mathrm{CSM}_{2}(1: 1)$ & 2500 & 256.70 & $141.30^{\mathrm{b}}$ & 51.10 & 35.70 \\
$\mathrm{CSM}_{3}(1: 2)$ & 0 & 255.00 & $142.30^{\mathrm{b}}$ & 52.80 & 33.50 \\
$\mathrm{CSM}_{3}(1: 2)$ & 2500 & 259.10 & $142.50^{\mathrm{b}}$ & 49.55 & 35.40 \\
Pooled S.E.M $^{\oplus}$ & & 0.960 & 0.250 & 0.570 & 0.460 \\
Two-way ANOVA (p-value) & & & & 0.113 \\
FM: CSM & & 0.563 & 0.011 & 0.231 & 0.322 \\
Protease & 0.121 & 0.035 & 0.657 & 0.123 \\
FM: CSM $\times$ Protease & & 0.425 & 0.035 & 0.092 & \\
\hline
\end{tabular}

†reatments means represent the average values of three aquaria per treatment. Duncan multiple range test was conducted for individual means only if there was a significant interaction (ANOVA: $\mathrm{P}<0.05$ ). Pooled S.E.M $\mathrm{M}^{\mathrm{t}}=$ pooled standard error of the mean. Means followed by the same letter are not significantly different. 
Table 9 Hematological parameters, differential red blood and white blood cells of Nile tilapia fed the experimental diets for 84 days.

\begin{tabular}{|c|c|c|c|c|c|}
\hline FM:CSM ratios & Protease $\mathrm{U} \mathrm{kg}^{-1}$ & Hemoglobin $\left(\mathrm{g}^{-1}\right)$ & Hematocrit (\%) & RBCs $\left(\times 10^{6} \mathrm{~mm}^{-3}\right)$ & WBCs $\left(\times 10^{5} \mathrm{~mm}^{-3}\right)$ \\
\hline \multicolumn{6}{|c|}{ Individual treatment means $^{\dagger}$} \\
\hline $\mathrm{CSM}_{1}(2: 1)$ & 0 & $16.25^{\mathrm{a}}$ & $24.50^{\mathrm{b}}$ & $1.75^{\mathrm{c}}$ & 36.80 \\
\hline $\mathrm{CSM}_{1}(2: 1)$ & 2500 & $16.80^{\mathrm{a}}$ & $25.95^{\mathrm{a}}$ & $2.15^{\mathrm{a}}$ & 37.60 \\
\hline $\mathrm{CSM}_{2}(1: 1)$ & 0 & $15.75^{\mathrm{b}}$ & $21.95^{\mathrm{c}}$ & $1.80^{\mathrm{b}}$ & 36.25 \\
\hline $\mathrm{CSM}_{2}(1: 1)$ & 2500 & $16.70^{\mathrm{a}}$ & $27.05^{\mathrm{a}}$ & $2.04^{\mathrm{a}}$ & 37.00 \\
\hline $\mathrm{CSM}_{3}(1: 2)$ & 0 & $13.50^{\mathrm{c}}$ & $23.35^{\mathrm{c}}$ & $1.84^{\mathrm{b}}$ & 36.95 \\
\hline $\mathrm{CSM}_{3}(1: 2)$ & 2500 & $15.95^{\mathrm{b}}$ & $24.80^{\mathrm{b}}$ & $2.03^{\mathrm{a}}$ & 35.75 \\
\hline Pooled S.E.M ${ }^{\star}$ & & 0.534 & 0.515 & 0.051 & 0.920 \\
\hline \multicolumn{6}{|c|}{ Two-way ANOVA (p-value) } \\
\hline FM: CSM & & 0.041 & 0.425 & 0.042 & 0.781 \\
\hline Protease & & 0.021 & 0.025 & 0.032 & 0.051 \\
\hline FM: $\mathrm{CSM} \times \operatorname{Pr}$ & ease & 0.026 & 0.041 & 0.049 & 0.072 \\
\hline
\end{tabular}

${ }^{\dagger}$ Treatments means represent the average values of three aquaria per treatment. Duncan multiple range test was conducted for individual means only if there was a significant interaction (ANOVA: $\mathrm{P}<0.05$ ). Pooled S.E.M ${ }^{\mathbb{q}}=$ pooled standard error of the mean. Means followed by the same letter are not significantly different. 
Table 10 Blood chemistry parameters of Nile tilapia fed the experimental diets for 84 days.

\begin{tabular}{|c|c|c|c|c|c|c|c|c|}
\hline FM:CSM ratios & Protease $\mathrm{U} \mathrm{kg}^{-1}$ & $\operatorname{ALT}\left(\mathrm{u} \mathrm{l}^{-1}\right)^{\#}$ & $\operatorname{AST}\left(\mathrm{u} \mathrm{l}^{-1}\right)^{\dagger}$ & Total protein $\left(\mathrm{g} \mathrm{dl}^{-1}\right)$ & $\operatorname{Albumin}\left(\mathrm{g} \mathrm{dl}^{-1}\right)$ & Globulin $\left(\mathrm{g} \mathrm{dl}^{-1}\right)$ & Calcium $\left(\mathrm{mg} \mathrm{dl}^{-1}\right)$ & Phosphorus (mg dl${ }^{-1}$ ) \\
\hline \multicolumn{9}{|c|}{ Individual treatment means ${ }^{\dagger}$} \\
\hline $\mathrm{CSM}_{1}(2: 1)$ & 0 & $25.05^{\mathrm{a}}$ & $14.80^{\mathrm{a}}$ & $4.74^{\mathrm{b}}$ & $1.91^{\mathrm{b}}$ & 2.83 & $8.21^{\mathrm{b}}$ & $4.2^{\mathrm{a}}$ \\
\hline $\operatorname{CSM}_{1}(2: 1)$ & 2500 & $21.80^{\mathrm{b}}$ & $12.70^{\mathrm{b}}$ & $5.03^{\mathrm{a}}$ & $2.20^{\mathrm{a}}$ & 2.83 & $9.50^{\mathrm{a}}$ & $4.7^{\mathrm{a}}$ \\
\hline $\mathrm{CSM}_{2}(1: 1)$ & 0 & $25.30^{\mathrm{a}}$ & $15.80^{\mathrm{a}}$ & $4.69^{b}$ & $1.83^{\mathrm{c}}$ & 2.86 & $7.20^{\mathrm{c}}$ & $3.15 b$ \\
\hline $\operatorname{CSM}_{2}(1: 1)$ & 2500 & $22.20^{\mathrm{b}}$ & $12.75^{\mathrm{b}}$ & $5.35^{\mathrm{a}}$ & $2.94^{\mathrm{a}}$ & 2.86 & $9.18^{\mathrm{a}}$ & $4.25 \mathrm{a}$ \\
\hline $\mathrm{CSM}_{3}(1: 2)$ & 0 & $25.75^{\mathrm{a}}$ & $17.80^{\mathrm{a}}$ & $4.86 \mathrm{~b}$ & $1.90^{\mathrm{b}}$ & 2.95 & $8.15^{b}$ & $2.85^{\mathrm{c}}$ \\
\hline $\mathrm{CSM}_{3}(1: 2)$ & 2500 & $21.85^{\mathrm{b}}$ & $13.80^{\mathrm{b}}$ & $4.73 b$ & $1.95^{\mathrm{b}}$ & 2.78 & $9.01^{\mathrm{a}}$ & $3.51 \mathrm{~b}$ \\
\hline Pooled S.E.M ${ }^{\Uparrow}$ & & 0.604 & 0.491 & 0.062 & 0.048 & 0.421 & 0.121 & 0.031 \\
\hline \multicolumn{9}{|c|}{ Two-way ANOVA (p-value) } \\
\hline FM: CSM & & 0.0421 & 0.045 & 0.001 & 0.004 & 0.121 & 0.031 & 0.001 \\
\hline Protease & & 0.001 & 0.001 & 0.003 & 0.001 & 0.321 & 0.022 & 0.012 \\
\hline FM: CSM $\times$ Prot & & 0.021 & 0.031 & 0.042 & 0.002 & 0.221 & 0.001 & 0.001 \\
\hline
\end{tabular}

${ }^{\dagger}$ Treatments means represent the average values of three aquaria per treatment. Duncan multiple range test was conducted for individual means only if there was a significant interaction (ANOVA: P < 0.05). Pooled S.E.M ${ }^{\star}=$ pooled standard error of the mean Means followed by the same letter are not significantly different

${ }^{\#} \mathrm{ALT}=$ Alanine aminotransferase $;{ }^{\dagger} \mathrm{AST}=$ aspartate aminotransferase 
Table 11 Two-way ANOVA (P-values) results of experimental diets on growth hormone $(\mathrm{GH})$ and insulin like growth factor I (IGF-I) gene expression of Nile tilapia

\begin{tabular}{lccc}
\hline \multirow{2}{*}{ Parameters } & \multicolumn{3}{c}{ Probability (P-value) } \\
\cline { 2 - 4 } & FM: CSM & Protease & FM: CSM $\times$ Protease \\
\hline GH in brain & 0.001 & 0.001 & 0.012 \\
GH in liver & 0.012 & 0.011 & 0.021 \\
IGF-I in brain & 0.001 & 0.001 & 0.001 \\
IGF-I in liver & 0.001 & 0.014 & 0.011 \\
\hline
\end{tabular}

